\title{
Archival Shadows in the Digital Age
}

\author{
Af Nanna Bonde Thylstrup
}

\begin{abstract}
Denne artikel undersøger ved hjoelp af begrebet data skyggen den måde, hvorpå kommerciel digitalisering forandrer hukommelseskulturer. Artiklen argumenterer for, at kommercielle digitale kulturelle hukommelsesarkiver såsom Google Books arbejder med to forskellige hukommelsesniveauer: et "front-end" niveau, hvor brugeren gives adgang til fortidens varker, og et "back-end" niveau, hvor brugerens egen fortid gemmes som en data skygge, men hvor adgangen til denne skygge kun gives til Google. Derfor bør kulturarvsinstitutioner, der hidtil primcert har tilstrcebt at give fuld adgang til fortiden qua Google Books, i den digitale kommercialiserede tidsalder også overveje hvilke implikationer deres samarbejde med Google Books har for brugernes privatliv.
\end{abstract}

\section{Introduction}

Cultural memory institutions have in the 20th century been governed according to a principle of access: access to the past and to knowledge. The logic behind contemporary cultural memory digitization programs such as Google Books seem to suggest that the more information we can accumulate and preserve about the past, the more educated we will be and the more progress we can effectuate. That means digitizing both historic material and integrating present voices into the past. But in dialectical tandem with the emphasis on access, another institutional concern has arisen, namely that of privacy.

Scholars increasingly pay attention to the long-term implications of what is interchangeably called "data shadows", "data doubles" (Poster 1990; Haggerty and Ericson 2000), "data bodies" (Critical Art Ensemble 1998), or "digital personae" (Roosendaal 2013), similar concepts that refer to the sum of all small traces of information that an individual leaves behind through everyday digital activities, such as sending emails, updating social media profiles, swiping credit cards, using ATMs and so on. The data shadow concept has become a serious matter of concern, because of the difficulties related to individual and collective control over who actually looks at an individual's digital traces, what conclusions they are drawing and what actions are taken by corporations and public institutions based thereon. The worry is that our past online activities will increasingly deter-
Nanna Bonde Thylstrup, ekstern lektor

SAXO, Københavns Universitet (nannab@hum.ku.dk) 
mine, and potentially damage, our future possibilities.

The concerns over the implications of data shadows bring to mind Hans Christian Andersen's tale, The Shadow, which depicts the inversion of the power relation between a man and his shadow (Andersen 1847). In Andersen's strange story the shadow side of a man's existence takes on a life of its own, grows strong and in the end overtakes its originator causing his demise: "The shadow was master now, and the master was the shadow". In addition to the obvious perspectives on people's dark sides, Andersen's story gives rise to another question that has become pertinent in the age of digitization: how much control can - and should - we have over our shadows?

The present article discusses these questions in relation to cultural memory institutions. The emergence of data shadows has significant implications for our relation to the past; the auspices of cultural memory institutions therefore seem to provide a rich environment from which to approach the new questions of control over one's past that emerge with digitization. On the one hand, these questions are well known to the theoretical regime of the archive as it developed at the height of poststructuralism by such cultural theorists as Jacques Derrida, Michel Foucault, and Gilles Deleuze and Felix Guattari. On the other hand, the new globalized, digitized and privatized archival milieu also presents new challenges that need contemporary theorization. I will therefore position the above question in a theoretical environment that draws on both familiar and novel cultural and social theories of the archive.

\section{Individual, collective and data shadows in cultur- al memory institutions}

Often shadows are depicted as unique attribute produced by individual bodies; yet, in some places such as cultural memory institutions, shadows can also take on a collective character. Here, the notion of the shadow is often used to denote the darker, ignored or even repressed, sides of history (Esposito 2008, Winter 2008.). But is also used to denote the influence of the some strands of past over others past in a more general way (Latour 2013, 172, 455). Thus cultural memory institutions are ripe with all kinds of shadows: cardinal shadows extending from cultural canons that tower over, and blot out, our view to alternative pasts; horrifying shadows born by past atrocities that silently and yet vociferously haunt our present; and prosaic shadows shaped by the productive traces of bygone quotidian practices that provide perspective on today's everyday lives.

Today it seems that cultural memory institutions provide only one possible answer to the question of how to deal with this multitude of shadows: they should live as long as possible and ideally be accessible to as many as possible, both the liminal, the ghastly and the canonical. This principle is partly owed to the fact that cultural memory institutions operate under a regime of scarcity, and so the shadows they contain, preserve and communicate are, no matter how inclusive their principles are, a select few.

Today, however, digitization has endowed cultural memory institutions with hitherto unseen possibilities for capturing and distributing shadows rooted in the past. Despite the occurrences of bit rot and chaotic data infrastructures, it has never been easier to collect and save information from users, to construct information infrastructures for navigational purposes in large amount of data and provide access to a much wider public. These new collection possibilities, together with commercializing governance structures in cultural memory institutions, have instigated new questions about the role of our past in the present and future and the levels of archival access to this past.

People usually visit archives to extract information from them, to approach shadows of the past. Yet, in the dynamic and relational environment of the digital, information is not only extracted from archives by users; archives also extract information from users and this reversed archival extraction procedure constructs another kind of shadows altogether that we might call data shadows, an enduring but ephemeral body of information that is both severed from, as well as attached to, the user and even holds a certain form of power over the user. Digitization has thus enabled cultural memory archives to work with access and preservation on two levels: on "front-end" collections and "back-end" systems.

In contrast to traditional memory shadows that are collected mainly according to a curatorial selective principle and kept within the auspices of a public institutional framework with a view to providing access, the digital inscriptions of data shadows 
are mainly collected and saved by public-private, or purely private, institutions, with no immediate intention to provide access to the public. This difference between analog and digital shadows indicates an uneasy bifurcation between different conceptions of access and past: a "front-end" past that is represented and accessible, and a "back-end" past that is blackboxed by technology and corporate veils. Thus, as Felix Stalder has noted, "as more of our data, and the programs to manipulate and communicate this data, move online, there is a growing tension between the dynamics on the front (where users interact) and on the back (to which the owners have access)" (Stalder 2012, 242).

Digital archival users thus effectively split into two entities, their "real" self and their data shadow. And the relation between human and shadow is complex. The parasitic nature of shadows for instance makes it natural to infer a close relation between a shadow and its originator, and even that "a shadow is sustained in existence by the continued existence of its originating source" (Todes 1975, 96). In reality, however, data shadows (much like "natural" shadows (Sorensen 2008, 30)) have the potential to survive the destruction of their originators. ${ }^{1}$ Even long after we are gone, our traces will still persist to the point where they can return in full form as ghostly presences or circulate in various servers as fragmented imprints that can enter into new contexts and fulfil new purposes.

The indelible nature of digital archives shadows is made more complex by their expressive power, which, much like analogue shadows (Stoichită 1997, $131,131)$, through projections, distortions and magnifications has the potential not only to provide an image of likeness of its originator, but also to create an index value that is variable dependent on the context: different contexts create different shadows. Hence, a library patron interested in terrorism could either be a potential terrorist him/herself or a researcher in the field of terrorism studies.

Importantly, digitization also reifies the very nature of shadows. "Natural" shadows are absences of light rather than substantive masses. Data shadows, by contrast, are reified shadows similar to shadows in a drawing shaded in on a white piece of paper with a pencil. The difference between absence and mass also affects how we may conceive of shadows in connection to privacy: where analogue shadows are by definition privations of light, digital shadows in contradistinction arise from a flooding of light that illuminates all spaces, eliminates privations and makes a condition of full observability. It is from this illuminated - and thus potentially controlled (Crary 2013, 16) - environment, that the malleable index of the user arises, an index that can be distributed at will but also offers itself for interpretation of its object like a hieroglyph waiting to be deciphered.

And finally, digitization redefines the very identity of material life in the sense that it facilitates a view on human bodies not as bounded essences, but in terms of quantifiable, recordable, enumerable, and encodable characteristics. This new mode of conception and production operates with a form of "subjectless patterning" (Galloway 2004, 86) in which individuals become "dividuals" in what Deleuze terms "control societies". Here, Deleuze says, "we're no longer dealing with a duality of mass and individual." Instead, "individuals become "dividuals," and masses become samples, data, markets, or "banks."" (Deleuze 1995, 180). Digitization thus dissipates individual shadows as "dividual" strings of pure, decontextualized and infinitely combinable, information, and one's access to these shadows hinges on ownership and/or whether one has the correct password or not.

\section{Governing shadows in archival assemblages}

In his book Delete: The Virtue of Forgetting in the Digital Age, legal scholar Viktor Mayer-Schönberger argues that there has been a paradigmatic reversal of the relation between forgetting and remembering in the digital age. "Since the early days of humankind," Mayer-Schönberger writes, "we have tried to remember, to preserve our knowledge, to hold on to our memories and we have devised numerous devices and mechanisms to aid us. Yet through millennia, forgetting has remained just a bit easier and cheaper than remembering" (Mayer-Schönberger $2009,48)$. No longer. Because of the digital revolution, he argues, it is easier and cheaper to keep everything rather than go through the palaver and timeconsuming process of deciding what to consign to oblivion. This applies to both private individuals and public and corporate institutions. When this keepeverything logic meets the equally persistent human desire to save as much as possible we move "from a world that is "private-by-default, public-through-ef- 
fort"" to one that is "public-by-default, private-witheffort."(boyd 2011) The result is an increased concern for the long-term implications of this inversion in which archival users inadvertently transmit more and more information about themselves with less and less control over the composition and conditioning of their data shadows ${ }^{2}$.

The incremental release and collection of personal information has often been treated through the lens of surveillance and related to Foucault's ideas of Bentham's penitentiary Panopticon. As Foucault has shown the invention of the Panopticon was characteristic of the disciplinary society as a representational regime established in confined spaces. In addition, "the penitentiary Panopticon was also a system of individualizing and permanent documentation" (Foucault 1995, 250). From each confined body was extracted a parallel body of knowledge, a "biographical knowledge" (Foucault 1995, 252) that would establish the criminal before the crime, and on the basis of this extracted knowledge develop "a systematic typology of delinquents" (Foucault 1995, 252-53). This typology, in turn, provided a schema of norms and deviations: a series of forms upon which individuals were induced to model themselves, thereby transforming themselves into subjects (Shaviro 2003). What emerged from this transposition was the genesis of a body double in the form police files, dossiers, and so forth. These two members, the empirical object and the transcendental subject, together formed a "strange empirico-transcendental doublet" (Foucault 2005, 347).

On the one hand, the disciplinary subject was an empirical entity, a free responsible body in space. On the other hand, he/she was a virtual object of knowledge, drawn up by bureaucratic documents. While each part corresponded to the other, they were not identical-the map was not the thing mapped. Instead, the modern human subject was produced within the interstices of a continual negotiation between the virtual and real. Digital archival users are in a similar way effectively split into two entities, their "real" self and their data shadow. Yet, unlike Foucault's disciplinary, centralized and confined spaces governed by public instances, today's data shadows are rather constructed in distributed technological landscapes and governed by an assemblage of public and private institutions.
In this historical sway from disciplinary societies to control societies, a shift takes place from a regime of disciplinary diagrammatics that worked primarily in terms of fixed spaces and identities to a regime oriented toward "mobility and anonymity" functioning through a "performance of contingent identities" and "its assemblages" (Hardt 1995, 36). These assemblages are not so much stable constellations, as they are constantly de- and reterritorializing formations produced by globalization, hereunder forces of mass digitization and commercialization processes. ${ }^{3}$ Within this historical shift cultural archives change from relatively stable and delineated disciplinary institutions to fluctuating and networked assemblages of control.

Thus, for instance, Google Books, through their scanning and networking activities, transpose the stable and sovereign infrastructures and frameworks of cultural memory institutions to a globally connected and constantly changing privatized sphere. As such Google Books presents a new dynamic in the archive; it breaks down, modifies and transforms traditional forms of cultural institutions in favor of the production of new ones. Put differently, Google Books deterritorializes traditional cultural memory archives by breaking down their infrastructures and governance frameworks. But they not only deconstruct institutions, they also subsequently reterritorialize the archival holdings in new functional nexuses shaped by new forms of globalizing activities and experiences. ${ }^{4}$

Thus, while archival works are increasingly lifted into a global landscape of pure and decontextualized information, their readers are in addition subjected to new forms of governance, transiting from the local institutional orders in disciplinary societies to new forms of territorialization in the emerging digital societies of control. Here notions of works, citizens and national space give way to information, global subjects and globalization; a development that has grave implications for the rights of archival users, in particular that of privacy. The ubiquity of personal data, the digital networks' deterritorializing effects on established jurisdictions, the modulating global contractual regimes of privatization increasingly displace constitutional rights regimes, and the sociospatial contexts that produces data are all activities that place immense pressure on the legal protection and conception of privacy, perhaps beyond recog- 
nition. Privacy has long been understood to require (among other things) personal control over the information concerning the self and a territorial rights regime to guarantee this control. But as a matter of empirical observation, in the expanding dataverse individuals exert less and less control over their own data and thus their shadows.

The implications of this are twofold. Firstly, the purpose of the Foucauldian transcendental shadow differs in public and private settings: while the use of biographical knowledge collected by public institutions resembles the practice outlined by Foucault, it changes radically in the setting of private corporations. Here data shadows are primarily collected by corporations that specialize in data-body economics with the purpose of carrying out targeted marketing aimed at individual customers or groups of customers. Based upon the profile of the data shadow, conclusions regarding possible future activity, in particular consumption, are drawn and offers are made.

Secondly, the new public-private archival environment sets up an entirely new frame of governance in which the rights of the user differ markedly from previous periods. Thus, in contradistinction to the public cultural memory institutions that feed it archival material, Google Books with its commercial framework have no obligations towards the public in terms of letting them access and edit their shadows and control its use.

Within these new archival assemblages the reified shadows of users attain a new role and value. Firstly, the shadow has become a valuable commodity. As the digital saying goes, "if you cannot see the price, it is highly likely that you are the commodity" and this holds especially true in Google Books that operates with two dominant forms of commodification processes: commodification of the act of inquiry and commodification of remembrance itself (Wark 2011). The former pertains to those who want to recall something from the archives and find themselves sold by memory platforms to advertisers. The latter pertains to the subjective compulsion to record own works and collections and share them with others; this latter form commodifies not the inquirer but the rememberer. As McKenzie Wark notes, both the desire to recall and to be recalled become new kinds of labor, yielding a new kind of commodification of subjectivity (Wark 2011). These commodifications present a process where commerce and communication coalesce, turning users into commodities in direct and indirect ways.

Moreover, as Zygmunt Bauman and David Lyon note, the data shadow constructed through these commodification processes "tends to be trusted more than the person, who prefers to tell their own tale" $(2013,13)$. In a sense then, data shadows begin to take centre stage as inanimate objects that are more reliable as witnesses than the frail and forgetful human memory. We would rather rely on a person's search history to tell us the truth about his or her digital whereabouts, than his/her account of them. This privileging of technological manifestations over bodily accounts is not limited to the digital realm but is part of a broader societal turn towards forensic ob-

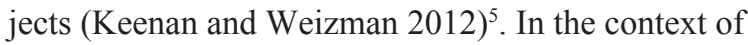
data, scholars have problematized this privileging of the documentary evidence provided by data shadows over accounts told by their flesh originators by questioning the reliability of evidentiary data representations and investigating whether the principle of due process-the prime directive that everyone is presumed innocent until proven guilty-is still practiced and maintained in the computational turn (Panda 2005; Steinbock 2005; Hildebrandt and Vries 2013; Kerr and Earle 2013).

Behind these legal, ethical and aesthetic qualms, a more fundamental question also arises as to how we might politically understand the role of data shadows. As already outlined concerned voices have portrayed data shadows as potential entrapments; as such data shadows appear as ominous and menacing presences that linger in the wake of the demise the 1990s utopian ideals of virtual identity. The notion of virtual identity belonged to the promise of the "empowered" and "limitless" realm of virtual reality whose anonymous, real-time, textual interface was thought to facilitate identity plays of various kinds (see for instance Žižek 1997); data shadows, by contrast, are malleable bodies of information that are collected on the basis of the involuntary, passive, or unconscious collecting of data by private corporations, and the voluntary, or active, dissemination of their own personal data by individuals. In a sense, then, the data shadow is what we pay with in the "back-end" systems of the archive for the empowerment we gain in the front end of collections. ${ }^{6}$ 


\section{Case study: constructing archival shadows in Google Books}

As a dominant commercial archival assemblage that operates as a major player in the realm of public memory institutions, Google Books is a particularly pertinent illustration of how digital cultural memory institutions construct a wide range of shadows with different modes of access. The following section therefore seeks to explicate and ground the theoretical concerns outlined above in an archival analysis of Google Books.

Both off- and online, the primary information subjects and senders are the readers themselves. In the library, readers' browsing and borrowing habits transmit information about them with varying degrees of formality and permanence; in digital archives such as Google Books readers transmit information about themselves by searching for particular terms, browsing through particular authors or subjects, clicking on particular results, or spending time on, copying, or printing out particular pages. The information attributes here are also quite similar to those in public libraries: in both cases, information is revealed about what a given reader is either reading or thinking about reading. Digitization changes the conditions, however, for how information is transmitted; it draws up new socio-spatial landscapes and constructs new information infrastructures.

Libraries are obviously social places; you enter them through a door and is immediately confronted with a series of social interactions from the information desk to the lending desk to other users. By contrast, you only enter Google Books, through a computer interface; therefore, while it may have a space, it entirely lacks a finite place (see Chun's discussions of space and place in Chun 2006, 37-48) and one is rarely confronted with the presence of others, even though they could number in the millions. In the latter, one can easily be lured into a feeling of solitude and privacy; in the former one is aware of the numerous contact points on different levels. These differences lead to a difference in behaviour: in contrast to physical libraries, digital archives encourage behaviour that disregards potentially inhibiting social norms, such as reading or borrowing books on potentially embarrassing topics. There is no sense inherent to the use of Google Books that one must behave in particular ways, or according to particular rules; it can thus feel entirely private, anonymous, and unobserved, which might allow individuals a greater sense of freedom than they might feel in a more decisively public, observable setting (Madden and Whitman 2010). Yet the information readers transmit in digital archives is considerably more detailed-potentially at the level of words or even pagesand much more closely tracked than that which they might transmit in public libraries. Moreover, there is a centralization and permanency of information in digital archives that is markedly different from the distributed and ephemeral information transmitted in analog archives.

Michael Zimmer, director of the Center for Information Policy Research at the University of WisconsinMilwaukee, has in an article recounted these differences in a fictional comparison between an analog patron, Libby, and a Google Books user, Netty (2008, 118). While Libby's interactions are "scattered among various agents, resulting in a fragmented dispersal of personal information," all of Netty's information activities involve Google, "allowing a level of consolidation not possible in Libby's scenario." Moreover, the types of information shared by Libby "tend to be incomplete, scattered verbal requests to librarians or booksellers, and the occasional transactional ... data provided to retailers," whereas Netty provides Google with "much more complete sets of information through her interaction"-accurate digital information that also allows for "simpler storage, processing, and sharing." Finally, there is a difference in terms of how voluntary Netty and Libby's information dispersions are. Libby, "voluntarily divulges information when she decides to interact directly with librarians, booksellers and so on," while Netty is "compelled to allow Google to track and collect her information browsing and usage habits" under Google's privacy policy (Google 2014). A similar analysis have been carried out by Elizabeth A. Jones and Joseph W. Janes in their article "Anonymity in a World of Digital Books" (Jones and Janes 2010).

Looking at the concrete case of how Google Books constructs and governs data shadows we can safely say that Google Books most certainly logs all search data with IP addresses, and associates these searches with a user's Google Account if logged in. Google can moreover share information in non-aggregated form with law enforcement, civil litigants, and with- 
in Google's own services; that means that Google collects several types of information, including device information, log information, location information, unique application numbers, local storage and cookies, and anonymous identifiers, which Google can then combine with your usage data from Google Search, Gmail, Google Reader, Google Maps, Picasa, or any of the company's myriad other services. Google Books also keeps track of users' page views. While they don't associate users' searches or the pages viewed by users with any personally identifiable information about him/her (the user logs in with his/ her Google Account), Google Books does associate non-personally identifiable information (IP address, cookies) with the books and pages that the user has viewed regardless of login (Google n.d.). The purpose of these logs is to enforce viewing limits to protect copyrighted books.

Google Books processes data in a series of countries worldwide, which makes it difficult to find information about the exact location of user information in Google Books and hence identify a stable jurisdiction (Schwartz 2013). Google Books nevertheless seems to keep a relatively high standard in terms of privacy compared to other books services (Electronic Frontier Foundation 2010). In fact, Google has received praise for fighting for user protection in the face of government surveillance (Electronic Frontier Foundation 2014). But even so, users of Google Books still rely on company policies, not state law, and these company policies will presumably be subject to easier and therefore many more amendments than official legal resolutions.

The question of privacy policies is also made complex by the increasing number of platforms from which one can access digital archives, such as social media sites like Facebook, Google+, Pinterest, and Twitter, as well as mobile devices such as Android. These platforms may all have significantly different privacy policies thus creating a labyrinthine archival privacy landscape of which a mapping is increasingly difficult to attain because of constant changes and reconfigurations, just as it-relatedly-exhibits the modulating landscape of privacy policies. While Google Books address privacy concerns, its privacy policies are subject to continuous changes and are in broad terms not enforceable obligations. The modulating nature of archival privacy policies evades any attempt at analytical stabilization and is, as such, inherently difficult to capture. These policies are, so to speak, moving targets that one can either freeze in time or raise to a more general level. There are pros and cons of both methodological approaches; the former guarantees more accuracy, but its object of study is also prone to becoming moribund due to the accelerating pace of agreements and related problematics. The latter guarantees less accuracy but can mitigate the black-boxed and fluctuating conditions of the above-outlined political environment by stabilizing the modulations within a larger structural rhythm of culture.

The result of these assemblage-like archival privacy formations is that it is becoming increasingly difficult to decode the way one's shadow is constructed, to which jurisdiction it belongs and how one is subjectified by it. With this in mind it seems even more necessary for cultural memory institutions to emphasize not only a commitment to remembering but also forgetting.

\section{The right to be forgotten}

The equation between more memory and more knowledge is as old as humankind itself. The dream of overcoming human memory's fallibility was expressed in particular by H. G. Wells when, in the 1930s, he wrote of a "world brain" through which "the whole human memory can be ... made accessible to every individual" (Wells 1939, 87; for more on the image of the world brain see Hillis et al 2013, 104-123). This also seems to be the aspiration of mass digitization, in its frequent celebratory claims of having now made access available to 10,20 or 30 million cultural works and its different ways of going about including user interaction with these historical objects. Few questions have been raised in regard to these quantitative aspirations that are to a large part fulfilled by public-private partnerships between libraries and Google Books. Yet, in 2014 the European Court of Justice ruled that Google must comply with requests from individuals to remove links on search results pointing to newspaper articles and other web pages that might cause embarrassment. ${ }^{7}$ The underlying premise of this ruling is that individuals retain a "right to be forgotten" (EC Commission 2014). By implication, Google and other Internet search companies could be forced to remove links, even if the information in question is itself accurate and lawful. At first glance the ruling has little to do with Google 
Books. But on further thought, the ruling prompts one to consider not only the limits of the workings of a specific search engine but also more fundamentally the limits of cultural memory today.

The regime of scarcity, to which cultural memory institutions once belonged, naturally put limits on how much was remembered and in many ways ensured stable regulatory principles for the collection and administration of cultural memory, since only designated public and private institutions had the capacity to aggregate and contain collections. Today's digital environment, by contrast, facilitates accumulation and distribution of cultural memory on a hitherto unprecedented scale and places them within novel public-private governance regimes. Moreover, it has facilitated a two-pronged collection and preservation practice in "front-end" collections and "backend" systems. Thus much more cultural material and many more patrons are under control and subject to a much wider distribution, without necessarily having access to the underpinnings of this control. And as such digital archives beg the premise of preservation and access outlined above.

Generally the official impetus for mass digitization is user emancipation in the form of education and the freedom to choose one's own path into the past. Today these themes are encapsulated within a more general claim to free choice and self-governance. Mass-digitized archives thus indicate freedom: freedom to surf collections without the constraints of disciplinary institutions and freedom to contribute to the construction and curation of one's own past. But as this article shows, digital archives also raise questions about control. Although digital archives offer the user a sense of free choices and self-governance, this sense is predicated on a series of standardization processes and governmental technologies that constrain the user on different levels, hereunder extensive logging of behavior, predefinition of the pools of information the user is free to choose from and commodification processes.

In H. C. Andersen's fairy-tale the shadow ended up more powerful than his former master. The story touches upon the difficulties associated with controlling the elements of one's shadow, and indicates the more general sentiment that control over elements of one's shadow could only ever be practiced in principle, since full control is always impossible (Derrida and Stiegler 2002, 31-40). Yet perhaps it is exactly the possibility of stating and proposing the principle, however illusionless the request is, that is valuable. The principle has been restated with the EU's new directive confirming the right to be forgotten in the face of leaking machines that seem to remember forever. And it should as such be present in the digital preservation strategies of cultural memory institutions as well, both in "front-end" collections and in "back-end" systems, so that evaluation and critique of how archives construct and condition individual and collective shadows can take place.

\section{Notes}

1. Sorensen provides us with the example of a tree that is constantly illuminated as it petrifies into stone. In this example the stone continues the shadow begun by the tree.

2. The sense of having one's privacy invaded is of course not a new phenomenon. In fact, popular and legal concerns about privacy have evolved pretty much in tandem with technological inventions. During the first half of the nineteenth century, as the new media of communication (books, newspapers, and magazines) permeated domestic spaces, the expression "wall of private life" assumed its legal and social significance. As the home became the place of conflicting passions, it emerged as a private fortress while conversely also becoming a microcosm crisscrossed by mobile borders. As Georges Teyssot notes, these crisscrossings "turned the private home into a battleground of conflicting interests, one that was constantly shifting and readjusting as society's norms changed and evolved," for instance with the invention of the telephone, which "was perceived as an unbearable infringement by some, while at the same time it ushered in personalized and individualized information-the tendrils became tentacles" $(2013,266)$. As Teyssot and several other scholars have shown, concerns over the impact of technology on privacy are well-rehearsed themes. Yet recent information scandals, growing out of a coming-together of political, corporate, technical, and individual investments and interests, suggest that today's technical environment does indeed present new problems to the conceptualization and practice of privacy. 
3. As Frederik Tygstrup (2014) shows a tradition already exists for describing social modernization as a process of deterritorialization from Karl Marx' theory of "original accumulation" (in which deterritorialization is to be taken quite literally in relation to agricultural land) to Michel Foucault's notion of discipline in which reterritorialization operates through the emergence of new disciplinary institutions regulating and organizing human behaviour within specific social spaces: the production site, the school, the prison, the barracks, the family, etc. In these disciplinary spaces human learning and experience unfold according to specific assemblages delineating specific ways of becoming a person in a disciplinary social setting, including the new communities of citizens of nation states. Today Foucault's disciplinary distribution of space withers away through a new surge of de-territorialisation where the fixed disciplinary space is dissolved into a new mobile landscape in which global networks of information connect distant places and novel modes of governance and thus gives rise to new archival assemblages. The Deleuzian conceptual apparatus of de- and reterritorialization thus registers these novel structures of our actuality.

4. As Deleuze and Guattari argue deterritorializations are always accompanied by reterritorializations, or at least by the impulse and temptation to reterritorialize: "What [modern societies] deterritorialize on the one hand, they reterritorialize on the other" (Deleuze and Guattari 1983, 257).

5. As Thomas Keenan and Eyal Weizman (2012) have shown, the act of witnessing changed significantly in the 20th century. Once the unreliability of witnesses was the decisive aspect of testimony, since it was interpreted as a power to register and convey the horror of events; yet, as Keenan and Weizman convincingly shows, the 1980 s saw the inauguration of an era of forensic evidence that took precedence over human witnessing (the use of DNA, 3D scans, nanotechnology, biomedical data, forensic data etc.)

6. As Critical Art Ensemble noted, "With the virtual body came its fascist sibling, the data body-a much more highly developed virtual form, and one that exists in complete service to the corporate and police state ... The data body is the total collection of files connected to an individual. No detail of social life is too insignificant to record and to scrutinize. From the moment we are born and our birth certificate goes online, until the day we die and our death certificate goes online, the trajectory of our individual lives is recorded in scrupulous detail. Education files, insurance files, tax files, communication files, consumption files, medical files, travel files, criminal files, investment files, files into infinity. ... The data body has two primary functions. The first purpose serves the repressive apparatus; the second serves the marketing apparatus" (Critical Art Ensemble 1998).

7. http://curia.europa.eu/juris/document/document print.jsf?doclang $=\mathrm{EN} \&$ docid $=152065$

\section{References}

Agre, P (2003). Surveillance and Capture: Two Models of Privacy. In N. Wardrip-Fruin \& N. Montfort (Eds.), The New Media Reader (p. 740-60). Cambridge, MA: MIT Press.

American Library Association (2009). Surveillance and Privacy. Chicago: ALA Office of Government Relations.

Andersen, HC (1847). Nye Eventyr Andet Bind. Kjøbenhavn: C. A. Reitzels Forlag.

Andersson, H (August 5, 2013). Tamerlan Tsarnaev Had Right-Wing Extremist Literature. BBC News US \& Canada.

Bauman, Z \& Lyon, D (2013). Liquid Surveillance: A Conversation. Cambridge, UK: Polity Press.

Berardi, F (2011). In After the Future, G. Genosko \& N. Thoburn (eds.). Edinburgh: AK Press.

Blinderman, I (April 21, 2013). Here's the Amazon Wish List of Alleged Boston Bomber Tamerlan Tsarnaev. NY Daily News.

Boyd, D (2011). Debating Privacy in a Networked World for the WSJ, November 20, 2011.

Chomsky, N (1971). Problems of Knowledge and Freedom. New York: Pantheon Books. 
Chun, WHK (2006). Control and Freedom: Power and Paranoia in the Age of Fiber Optics. Cambridge, MA: MIT Press.

Cowan AL (May 31, 2006). Four Librarians Finally Break Silence in Records Case. New York Times.

Crary, J (2013). 24/7: Late Capitalism and the Ends of Sleep. London: Verso.

Critical Art Ensemble (1998). Flesh Machine: Cyborgs, Designer Babies, and New Eugenic Consciousness. Brooklyn, NY: Autonomedia.

Deleuze, G \& Guattari, F (1983). Anti-Oedipus: Capitalism and Schizophrenia. Minneapolis: University of Minnesota Press.

Deleuze, G (1995). Postscript on Control Societies. In G. Deleuze (eds.), Negotiations 1972-1990, (pp. 177-82). New York: Columbia University Press.

Derrida, J \& Stiegler, B (2002). Echographies of Television: Filmed Interviews. Cambridge, UK: Polity Press.

EC Commission (2014). Factsheet on the "Right to be Forgotten" Ruling (C-131/12).

Eisenberg, A (May 25, 2013). Bequeathing the Keys to Your Digital Afterlife. New York Times.

Electronic Frontier Foundation (2012). E-Reader Privacy Chart, 2012 Edition.

Electronic Frontier Foundation (2014). Who Has Your Back? A Report from the Electronic Frontier Foundation.

Esposito, E (2008). Social forgetting: A Systems Theory Approach. In A. Erll and A. Nünning (Eds.), Cultural Memory Studies: An International and Interdisciplinary Handbook (pp. 181-190). Berlin: Walter de Gruyter.

Foucault, M (1995). Discipline and Punish: The Birth of the Prison. New York: Vintage Books.

Foucault, M (2005). The Order of Things: An Archaeology of the Human Sciences. London: Routledge.
Galloway, A (2004). Protocol: How Control Exists After Decentralization. Cambridge, MA: MIT Press.

Google (2014). Privacy and Terms. google.com/policies/privacy/.

Google (nd.). Does Google Keep Track of the Pages I'm Viewing or the Books I Read? https://support. google.com/books/answer/43733?hl=en\&ref_topic $=4359341$.

Haggerty, KD \& Ericson, RV (2000). The Surveillant Assemblage. The British Journal of Sociology 51(4), 605-22.

Hildebrandt, M \& de Vries, K (2013). Privacy, Due Process and the Computational Turn: The Philosophy of Law Meets the Philosophy of Technology. Abingdon, UK: Routledge.

Hillis, K et al (2013). Google and the Culture of Search. New York; London: Routledge.

Jones, EA \& Janes, JW (2010). Anonymity in a World of Digital Books: Google Books, Privacy, and the Freedom to Read. Policy \& Internet 2(4), 43-75.

Keenan, T \& Weizman, E (2012). Mengele's Skull: The Advent of a Forensic Aesthetics. Berlin: Sternberg Press.

Kerr, I \& Earle, J (2013). Prediction, Preemption, Presumption: How Big Data Threatens Big Picture Privacy. Stanford Law Review Online 65.

Krysa, J (2006). Curating Immateriality: The Work of the Curator in the Age of Network Systems. In J Krysa (eds.), Curating Immateriality: The Work of the Curator in the Age of Network Systems (pp. 7-25). Brooklyn, NY: Autonomedia.

Latour, B (2013). An Inquiry into Modes of Existence: An Anthropology of the Moderns. Cambridge, MA: Harvard University Press.

Madden, M \& Smith, AW (2010). Reputation Management and Social Media: How People Monitor Their Identity and Search for Others Online. Washington, DC: Pew Internet \& American Life Project. 
Mayer-Schönberger, V (2009). Delete: The Virtue of Forgetting in the Digital Age. Princeton: Princeton University Press.

Mayer-Schönberger V \& Cukier, K (March 11, 2014). Your High School Transcript Could Haunt You Forever. The Atlantic.

Panda, S (2005). The Procedural Due Process Requirements for No-Fly Lists. Pierce Law Review $4(1), 121-54$.

Poster, M (1990). The Mode of Information: Poststructuralism and Social Context. Chicago: University of Chicago Press.

Roosendaal, A (2013). Digital Personae and Profiles in Law: Protecting Individuals' Rights in Online Contexts. Oisterwijk, The Netherlands: Wolf Legal Publishers.

Schrage, M (January 29, 2014). Big Data's Dangerous New Era of Discrimination. Harvard Business Review Blog.

Schwartz, PM (2013). The EU-U.S. Privacy Collision: A Turn to Institutions and Procedures. Harvard Law Review. 126 (7), 1966-2009.

Shaviro, S (2003). Connected: Or, What It Means to Live in the Network Society. Minneapolis: University of Minnesota Press.

Sorensen, RA (2008). Seeing Dark Things: The Philosophy of Shadows. New York: Oxford University Press.

Steinbock, DJ (2005). Data Matching, Data Mining, and Due Process. Georgia Law Review 40(1), 1-84.

Stoichiță, VI (1997). A Short History of the Shadow. London: Reaktion Books.

Stalder, F (2012). Between Democracy and Spectacle: The Front-End and the Back-End of the Social
Web. In M Mandiberg (ed.), The Social Media Reader, (pp. 242-256). New York: New York University Press.

Strømmen, Ø (July 18, 2013). Boston Bombers' Reading List. Hate Speech International.

Teyssot, G (2013). A Topology of Everyday Constellations. Cambridge, MA: The MIT Press.

Thylstrup, N (2014). The Politics of Mass Digitization. Copenhagen: University of Copenhagen.

Todes, S (1975). Shadows in Knowledge. D Ihde and RM Zaner (eds.), Studies in Phenomenology and Existential Philosophy (pp. 95-113). The Hague: Nijhoff.

Tygstrup, F (2014, forthcoming). Reading Space. In A Nünning et al. (eds.), Experiencing Space - Spacing Experience. New York; Berlin: De Gruyter.

Wark, M (2011). Book Review: Save As . . . Digital Memories. Memory Studies 4(4), 484-86.

Wells, HG (1938). World Brain. Garden City: Doubleday, Doran \& Co.

Winter, J (2008). Sites of Memory and the Shadow of War. In A Erll \& A Nünning (eds.), Cultural Memory Studies: An International and Interdisciplinary Handbook (pp. 61-76). Berlin: Walter de Gruyter.

Wortham, J. (July 17, 2010). As Facebook Users Die, Ghosts Reach Out. New York Times.

Zimmer, M (2008). Privacy on Planet Google: Using the Theory of "Contextual Integrity" to Clarify the Privacy Threats of Google's Quest for the Perfect Search Engine. Journal of Business \& Technology Law 3(1), 109-26.

Žižek, Slavoj (1997). Cyberspace, Or, The Unbearable Closure of Being. In The Plague of Fantasies (pp. 127-167). London: Verso. 